\title{
Properties of Color, Texture and Sensorial Analysis of Small Cowpea Bean Bunuelounder Deep Frying
}

\author{
Armando Alvis Bermudez ${ }^{1 *}$, Guillermo Arrazola Paternina' and Elvis J. Hernandez ${ }^{2}$ \\ 'Department of Engineering, Food Engineering Program, Vegetable Processes and Agroindustry \\ Research Group, University of Cordoba, Carrera 6 N 76-103, Cordoba, Colombia; \\ aalvisbermudez@correo.unicordoba.edu.co,guillermo.arrazola@ua.es \\ ${ }^{2}$ Department of Agro-Industrial Engineering, Innovation and Development of Food \\ Processes (DESINPA), University of Sucre, Sincelejo-Sucre, 70001, Colombia; \\ elvis.hernandez@unisucre.edu.co
}

\begin{abstract}
Objective: This study aimed at determining color, texture and sensorial acceptance degree of cowpea bean bunuelos under deep frying. Materials/Methods: Frying stage of the bunuelos was 480 seconds, and soybean oil was used, heating up to 150,160 and $170^{\circ} \mathrm{C}$. Color measurement was made both to crust and crumb of bunuelos, after 2 hours of frying. Textural Procedural Analysis test (TPA) was performed. A sensory evaluation was carried out with 60 untrained tasters. Findings: Crust and crumb color varied with formulation and temperature increase, becoming less bright, less red and less yellow. All texture variables varied according to the process temperature and formulation. Sensory analysis determined that formulations studied are pleasant for consumers in terms of the studied attributes. Improvements: Fried small bunuelos with superior quality attributes such as color, texture and sensory can be made with cowpea beans.
\end{abstract}

Keywords: Deep Frying, Cowpea Bean bunuelos, Quality Attributes, Texture

\section{Introduction}

Cowpea bean (Vigna unguiculata) or black-eyed pea is a grain legume that represents an important source of micro and macronutrients $s^{\frac{1}{}}$, especially of dietary protein $\stackrel{2,3}{ }$. Seed has a high content of protein $(19.5 \% \text { and } 27.3 \% \mathrm{w} / \mathrm{w})^{4}$, it has several essential amino acids in balanced proportions. Generally, some products are elaborated from cowpea bean seed such as: astringents, aperitifs, laxatives, anthelmintic, aphrodisiac, diuretic, and tonic for the liver, and others ${ }^{3}$.

For food, there are different preparations from this legume, such as the small BunueloCosteno. This is a handmade product resulting from a paste made mixture from ground beans, water, spices, eggs, milk, and other ingredients. The elaboration includes steps such as seeds soaking and grinding, seed coat separation and a final grinding before obtaining the paste. Texture is a highly important sensory attribute for the preference of a fried product and is a critical parameter in product ${ }^{5}$ final quality. It is expected that a superior quality fried product has a crunchy crust between 1 and $2 \mathrm{~mm}$, with a cooked, moist and soft center ${ }^{6}$ as an indicator of freshness and high quality.

Texture profile analysis (TPA) is a simulation of a sample chewing by means of texture analyzer equipment. It consists of compressing a food the size of a bite to mimic the action of teeth and includes analysis of different texture characteristics of a sample $\mathrm{e}^{--9}$.

Before making the decision to consume a food, one of the organoleptic parameters that havemajor influence is the visual aspect, especially color, which may cause

${ }^{*}$ Author for correspondence 
rejection making a product not suitable for consumption or otherwise, acceptance. Heat and mass transfer that take place during frying cause physicochemical changes, affecting the color of fried products. Process variables such as oil temperature, oil type and frying time affect color of fried products ${ }^{10}$. Color changes in deep frying may be due to temperature increase by caramelization reactions and proteins and carbohydrates interaction, which is known as the "Maillard reaction" $\underline{11}$, as well as caramelization of sugars. In this study, color, texture and degree of sensorial acceptance of deep frying cowpea bean bunuelos were determined.

\section{Materials and Methods}

\subsection{Preparation of Cowpea Masses and Deep Frying of bunuelos}

2 formulations were prepared from the resulted bean flour as shown in Table 1 . Constituents were mixed and shaken manually until a homogeneous paste was obtained and reserved in plastic containers and in refrigeration until use.

The frying process of each formulation was carried out with soybean oil in a 5-liter GMS electric fryer at three temperatures: 150 (T1), 160 (T2) and $170^{\circ} \mathrm{C}$ (T3) during a frying period of 480 seconds. After the end of each sample time, bunuelos were taken out of oil and put on absorbent paper at room temperature to remove superficial oil and, thus, avoiding alteration of results.

\subsection{Evaluation of bunuelos' Color}

Color measurement of bunuelos (both crust and crumb) was carried out 2 hours after frying. A Colorflex EZ colorimeter and the scale named CIE with the coordinates $\mathrm{L}^{*}, \mathrm{a}^{*}$ and $\mathrm{b}^{*}$ was used.

\subsection{Texture Profile Analysis (TPA) of bunuelos}

Analysis of texture profile by double compression: TPA test was performed on the completely fried bunuelos at the end of 480 seconds with a texturometer TA.XTPlus by means of two compressions simulating human bite with $2.5 \mathrm{~cm}$ cubes, using a circular plate of $75 \mathrm{~mm}$ diameter with rod base. Test conditions were $1 \mathrm{~mm} / \mathrm{s}$, post-test speed $10 \mathrm{~mm} / \mathrm{s}$, compression distance $10 \mathrm{~mm}$ and load cell $30 \mathrm{~kg}$. In the texture profile analysis (TPA) characteristics of hardness, cohesiveness, adhesiveness, gumminess, elasticity and chewiness were determined.
Texture profile analysis by puncture: A $2 \mathrm{~mm}$ cylindrical rod was used for puncture texture analysis.

\subsection{Sensory Evaluation}

A sensory evaluation was carried out with 60 untrained tasters. The criteria for participating in the assay were: being a habitual consumer of fried products, not being allergic to raw materials used or another food and time availability. Fry samples at $150^{\circ} \mathrm{C}$ for each formulation were selected for the test, since they were the ones with the lowest oil absorption; a 9-point mixed hedonic scale was used to evaluate attributes of color, smell, taste and texture. General acceptance was as well evaluated ${ }^{12}$.

Samples were served hot $\left(60^{\circ} \mathrm{C}\right)$ in random order coded with 3-digit numbers. Each panelist was given a qualification format with the samples and a glass of water to clean their palate between sample and sample.

\subsection{Statistical Analysis}

An experimental design with 3 completely randomized repetitions of two factors (formulation and temperature of frying) was used. Results of combination of factors were analyzed by ANOVA of double classification and tests of multiple ranges applying Duncantest. For the sensory analysis, an ANOVA of a single factor, frying temperature $\left(150^{\circ} \mathrm{C}\right)$ was used.

\section{Results and Discussion}

\subsection{Color Evaluation}

Values obtained from $\mathrm{L}^{*}, \mathrm{a}^{*}$ and $\mathrm{b}^{*}$ for crust showed significant differences among the different formulations as indicated in Table 2, where temperature, formulation and formulation-temperature interaction were significant.

The results show that changes in color of the crust increased significantly in the bunuelos of the formulations, especially in the F2. This could be due to the amount of sugars present and all the reactions triggered from these. Regarding the temperature, the $\mathrm{L}^{*}$ parameter becomes smaller, that is, darker, probably due to the greater heat flow experienced by the product during frying. A higher heat flow should increase surface temperature, increasing amount of Maillard products and caramelization and production of a darker crust. $\mathrm{In}^{\frac{13}{3}}$ reported the same trend in research conducted in doughnuts. 
The yellow-blue hue ranged between 13.92 and 33.97 showing inclination towards the yellow color in its positive axis, and the parameter $\mathrm{a}^{*}$ was shown between a range of 12.12 to 18.92 in its positive axis leaning more to the red color. Through observation, a lighter color was confirmed, more golden for F1 formulation than for F2 formulation.

Moisture of formulations is another incident factor in color analysis. In ${ }^{14}$ found a positive correlation between light and moisture in food, implying that lower water content leads to decrease in brightness. Nonetheless, in this case, formulation F1 has lower moisture content at the same temperature and, in comparison with formulation F2, its brightness is higher. This difference could be marked by a higher content of sugars in formulation F2. In $\frac{15}{5}$ found that this is due to production of dark pigments and decomposition of carbohydrates that facilitate the Maillard reaction. For the same formulation, the effect of the correlation is evidenced, since as the frying temperatures increased, the moisture decreased and with this, gloss of the product crust.

Through variance analysis, a significant difference was found among crumb samples as shown in Table 2, where oil temperature, formulation and temperatureformulation interaction variables were significant for all variables $\left(L^{*}, a^{*}\right.$ and $\left.b^{*}\right)$. Nonetheless, very close results are evident between formulation F1 and F2. Yellow-blue hue ranged between 20.05 and 26.47, showing inclination

Table 1. Formulations of masses prepared from cowpea beans

\begin{tabular}{llllll}
\hline & \multicolumn{4}{l}{ Quantity in mixture (\%) } & \\
\cline { 2 - 6 } Formulation & Flour & Water & Milk & Egg & Salt \\
\hline F1 & 50 & 40 & - & 8 & 2 \\
F2 & 47,4 & - & 42,6 & 8 & 2 \\
\hline
\end{tabular}

Table 2. Colorimetric parameters for the different treatments

\begin{tabular}{|c|c|c|c|}
\hline \multicolumn{4}{|l|}{ Crust } \\
\hline \multirow[b]{2}{*}{ Treatment } & \multicolumn{3}{|l|}{ Parameters } \\
\hline & $L \pm S D$ & $a \pm S D$ & $b \pm S D$ \\
\hline $\mathrm{F} 1 . \mathrm{T} 1^{*}$ & $46,68 \pm 0,00^{\mathrm{a}}$ & $18,34 \pm 0,01^{c}$ & $32,97 \pm 0,05^{a}$ \\
\hline F1.T2 & $42,41 \pm 0,00^{\mathrm{b}}$ & $17,03 \pm 0,01^{\mathrm{d}}$ & $32,04 \pm 0,03^{b}$ \\
\hline F1.T3 & $30,15 \pm 0,01^{\mathrm{d}}$ & $30,15 \pm 0,01^{\mathrm{a}}$ & $20,14 \pm 0,02^{\mathrm{d}}$ \\
\hline $\mathrm{F} 2 . \mathrm{T} 1$ & $32,14 \pm 0,02^{c}$ & $18,92 \pm 0,01^{\mathrm{b}}$ & $24,51 \pm 0,03^{\mathrm{c}}$ \\
\hline $\mathrm{F} 2 . \mathrm{T} 2$ & $28,92 \pm 0,01^{\mathrm{e}}$ & $16,33 \pm 0,01^{\mathrm{e}}$ & $17,73 \pm 0,03^{\mathrm{e}}$ \\
\hline F2.T3 & $25,99 \pm 0,02^{\mathrm{f}}$ & $12,12 \pm 0,02^{\mathrm{f}}$ & $13,98 \pm 0,04^{\mathrm{f}}$ \\
\hline \multicolumn{4}{|l|}{ Crumb } \\
\hline \multirow[b]{2}{*}{ Treatment } & \multicolumn{3}{|l|}{ Parameters } \\
\hline & $L \pm S D$ & $a \pm S D$ & $b \pm S D$ \\
\hline F1.T1 & $70,46 \pm 0,01^{a}$ & $2,16 \pm 0,01^{f}$ & $20,05 \pm 0,00^{\mathrm{f}}$ \\
\hline F1.T2 & $69,21 \pm 0,00^{\mathrm{b}}$ & $2,56 \pm 0,01^{\mathrm{d}}$ & $21,89 \pm 0,01^{\mathrm{d}}$ \\
\hline F1.T3 & $68,30 \pm 0,00^{c}$ & $3,18 \pm 0,03^{\mathrm{a}}$ & $26,47 \pm 0,01^{\mathrm{a}}$ \\
\hline F2.T1 & $58,96 \pm 0,01^{\mathrm{f}}$ & $2,44 \pm 0,01^{\mathrm{e}}$ & $21,57 \pm 0,00^{\mathrm{e}}$ \\
\hline $\mathrm{F} 2 . \mathrm{T} 2$ & $61,94 \pm 0,00^{e}$ & $3,17 \pm 0,01^{\mathrm{b}}$ & $25,86 \pm 0,02^{b}$ \\
\hline F2.T3 & $63,43 \pm 0,00^{\mathrm{d}}$ & $2,75 \pm 0,01^{\mathrm{c}}$ & $24,70 \pm 0,01^{\mathrm{c}}$ \\
\hline
\end{tabular}

Different letters in the same column indicate significant difference between treatments by the Duncan method at $5 \%$ significance, *T.F. Temperature and Formulation 
towards the yellow color. The parameter a* was shown between a range of 2.16 to 3.18 on its positive axis, which leans slightly red. Visual observation confirmed a very similar color in all treatments.

Because of the crumb analysis, it is stated that due to the little interaction of the surface of the crumb with the oil at elevated temperature, there is no significant color change, since the crust is located between these two, preventing passage of heat directly.

\subsection{Texture Analysis}

\subsubsection{Texture Profile Analysis by Double}

\section{Compression}

Table 3 shows average values of texture variables. For all variables, incidence of temperature, formulation and temperature-formulation interaction was significant.

As the temperature increases, hardness increases. This effect may be due to the relationship between temperature and water content. When the temperature is higher, more moisture is lost; low humidity is translated into high hardness as water gives softness to the products. $\operatorname{In}^{16}$ reported that decrease in moisture generates increase in all texture variables of food products, including hardness. Comparable results have been reported in tilapia sausages ${ }^{8}$, chicken nugget ${ }^{17}$ and felipita, harton and topocho bananas ${ }^{\frac{18}{}}$.

In addition, it was observed that texture of samples of higher temperature was closed, i.e., the alveoli formed by the evaporation of water are uniform and small. This is because at a higher temperature changes of food matrix occur much faster $\stackrel{19,13}{\underline{13}} . \mathrm{In}^{20}$ reported that a more compressed crumb may contribute to obtain a firmer texture. For the hardness, the samples of the F1 formulation were higher in any of the cases with respect to the samples of the F2 formulation. This may also be due to the final moistures that were greater for the F2 formulation. Additionally, the protein network favors the product softness.

$\mathrm{In}^{21}$ reported hardness values for water bread that oscillate between 8.6 and $15 \mathrm{~N}$. In ${ }^{\frac{13}{3}}$ reported the hardness has an inverse relationship with fat content, since fat softens the crumb of baked products. Comparable results were reported by ${ }^{22}$. In ${ }^{1}$ reported hardness values in fried akaras between 6.5 and 11.6 Nagreeing also with the fact that presence of air gives softness to the product. As oil temperature increased, adhesiveness was lower for the same formulation. The proteins of formulation F2 can contribute to obtain higher stickiness values. The results with respect to other authors are good, since this characteristic is not desirable in fried products ${ }^{23}$. $\operatorname{In}^{21}$ reported adhesive values of $-0.33 \mathrm{kgf} . \mathrm{mm}$ in water bread. For the F1 formulation there was a slight tendency to decrease cohesiveness as the temperature increases, this may be because of the response variable is affected by absorption of oil, since it interferes with the interaction of proteins and carbohydrates each. Comparable results were obtained by $\underline{13}$ with values of 0.26 and 0.57 in doughnuts.

On the other hand, for the F2 formulation, cohesiveness increases at higher temperatures. This result could be supported by the reinforced protein network that could be generated by addition milk. Also, oil absorption for these samples was lower. These characteristics make Samples more resistant to deformation and rupture. $\mathrm{In}^{21}$ reported cohesiveness values between 0.39 and 0.47 in water bread; $\operatorname{In}^{24}$ reported values between 0.30 and 0.54 in bunuelos with emulsifier. $\mathrm{In}^{1}$ reported

Table 3. Texture characteristics by double compression for the different treatments

\begin{tabular}{|c|c|c|c|c|c|c|}
\hline \multirow[b]{3}{*}{ Treatment } & \multicolumn{6}{|c|}{ TextureCharacteristics } \\
\hline & Hard. & Adh. & Coh. & Elas. & Gum. & Chew. \\
\hline & $\mathrm{N}$ & $\mathrm{kg} \mathrm{m} / \mathrm{s}^{2}$ & & & $\mathrm{~kg} \mathrm{~m} / \mathrm{s}^{2}$ & $\mathrm{Kg}$ \\
\hline F1.T1 & $67,74^{\mathrm{b}}$ & $-0,44^{\mathrm{c}}$ & $0,53^{\mathrm{b}}$ & $0,85^{\mathrm{a}}$ & $36,42^{\mathrm{b}}$ & $3,16^{c}$ \\
\hline F1.T2 & $67,78^{\mathrm{b}}$ & $-0,62^{b}$ & $0,54^{\mathrm{b}}$ & $0,84^{\mathrm{b}}$ & $36,61^{b}$ & $3,18^{\mathrm{c}}$ \\
\hline F1.T3 & $117,54^{\mathrm{a}}$ & $-1,02^{\mathrm{a}}$ & $0,47^{\mathrm{c}}$ & $0,83^{c}$ & $55,85^{\mathrm{a}}$ & $4,73^{\mathrm{a}}$ \\
\hline F2.T1 & $59,11^{\mathrm{d}}$ & $-0,69^{b}$ & $0,40^{\mathrm{d}}$ & $0,84^{\mathrm{b}}$ & $24,20^{\mathrm{d}}$ & $2,07^{\mathrm{d}}$ \\
\hline $\mathrm{F} 2 . \mathrm{T} 2$ & $62,85^{\mathrm{c}}$ & $-0,77^{b}$ & $0,47^{\mathrm{c}}$ & $0,85^{\mathrm{a}}$ & $24,99^{\mathrm{d}}$ & $2,18^{\mathrm{d}}$ \\
\hline F2.T3 & $67,04^{\mathrm{b}}$ & $-1,00^{\mathrm{a}}$ & $0,58^{\mathrm{a}}$ & $0,85^{\mathrm{a}}$ & $29,38^{c}$ & $3,42^{\mathrm{b}}$ \\
\hline
\end{tabular}

Different letters in the same column indicate significant difference among treatments by the Duncan method at $5 \%$ of significance 
values b etween 0.15 and 0.23 in fried akaras. Values of elasticity varied between 0.83 and 0.85 ; these are good since the samples recovered between 83 and $85 \%$ after the deformation.

The alveolar formation, result of the evaporation of water, protein and starch network, the final content of oil and moisture, among other factors, contribute to the product recovery. $\mathrm{In}^{21}$ reported elasticity values around $50 \%$ in water bread. $\mathrm{In}^{24}$ reported elasticity values between 0.86 and 0.90 in bunuelos with emulsifier; $\mathrm{In}^{1}$ reported in fried akaras values between 0.58 and $0.61 \mathrm{~mm}$. Gumminess increases as the temperature increases for the same formulation and the average values of the formulation F1 are greater than those of the formulation F2, this same behavior is presented by chewiness, since both response variables are related to each other. Nonetheless, for both formulations at 150 and $160^{\circ} \mathrm{C}$ there is no significant difference in the variable.

The most chewable products are those that have the lowest chew value since, from the sensory point of view, it requires more time for gobbling in the mouth before swallowing 21 . The increase in gumminess and chewiness for the same formulation must be formed by gelatinization of starches and protein denaturation, leading to more strength and energy required to disintegrate the samples until they can be swallowed. $\operatorname{In}^{21}$ reported a positive correlation between hardness and gumminess, i.e., greater hardness, greater gumminess and chewiness; also reflected in this study ${ }^{1}$ obtained chewiness values between 0.6 and $1.4 \mathrm{~N} \mathrm{~mm}$ in akaras, well below those obtained in this study.

Analysis of texture profile by puncture: Penetration force values of crust for the different treatments are shown in Table 4. Through ANOVA, it was found that frying temperature and formulation, as well as its temperature-formulation interaction, was significant and when applying Duncan's test, all means show significant differences.

As the temperature increases, crusts become harder and average values of $\mathrm{F} 1$ formulation are greater than those from $\mathrm{F} 2$ formulation, except at $150^{\circ} \mathrm{C}$. These characteristics occur because as the temperature increases, changes in food structure occur more quickly and therefore the crust will form in a shorter time ${ }^{25}$. In addition, crusts are dry surfaces and are also related to the final product humidity. Lower humidity reached greater hardness of the crust $t^{13,24}$ found that the moisture migration to the crust makes it softer. Different val- ues of crust firmness have been reported for several products such as water bread that range between 16 and $22 \mathrm{~N}^{21}$, for cassava sour starch bunuelos between 21 and $28 \mathrm{~N}^{24}$, and for doughnut crust, between 0.77 and $2,61 \mathrm{~N}^{13}$.

\subsection{Sensory Evaluation}

Table 5 shows average values obtained for each attribute evaluated for the treatments. Scores obtained are acceptable since in none of the cases they enter on the displeasure scale. No significant difference was found in any of the attributes. In the case of color, the values of the means of the formulations show formulation 1 more visually attractive than formulation 2 , this may be because in the first case there is a marked browning and in the formulation 2 it is darker. In ${ }^{12}$ reported average

Table 4. Texture characteristics by puncture for the different treatments

\begin{tabular}{ll}
\hline Treatment & $\begin{array}{l}\text { Hardness Characteristics of } \\
\text { the Crust (N) }\end{array}$ \\
\hline F1.T1 & $5,57^{\mathrm{f}}$ \\
F1.T2 & $10,18^{\mathrm{b}}$ \\
F1.T3 & $15,25^{\mathrm{a}}$ \\
F2.T1 & $7,30^{\mathrm{e}}$ \\
F2.T2 & $8,65^{\mathrm{d}}$ \\
F2.T3 & $9,46^{\mathrm{c}}$ \\
\hline
\end{tabular}

Different letters in the same column indicate significant difference among treatments by the Duncan method at $5 \%$ of significance

Table 5. Average values of sensory attributes evaluated for fried bean buñuelosat $150^{\circ} \mathrm{C}$

\begin{tabular}{lll}
\hline & Formulation & \\
\cline { 2 - 3 } Attributes & Formulation 1 & Formulation 2 \\
\hline Color & $6,6^{\mathrm{a}}$ & $6,3^{\mathrm{a}}$ \\
Smell & $6,4^{\mathrm{a}}$ & $6,3^{\mathrm{a}}$ \\
Taste & $6,2^{\mathrm{a}}$ & $5,9^{\mathrm{a}}$ \\
Texture & $5,6^{\mathrm{a}}$ & $5,6^{\mathrm{a}}$ \\
General & $6,4^{\mathrm{a}}$ & $6,2^{\mathrm{a}}$ \\
Acceptance & & \\
\hline
\end{tabular}

Different letters in the same row indicate significant difference among treatments 
color values between 7.2 and 7.7 in fried akaras using 3 cultivars of cowpea beans.

In the case of smell, it could be due to the characteristic smell of flour prevailing over the addition or not of milk. $\mathrm{I} n \frac{12}{}$ reported values between 6.7 and 7.1 in fried akaras; values above those found in this study. $\operatorname{In}^{26}$ found values between 6.08 and 7.04 in crumb of akaras prepared with alkaline salt solutions; like those found in this study. For flavor, higher average values were found for the F1 formulation, which ranged in both cases on the 'I like it slightly' scale. In ${ }^{12}$ reported values ranging between 6.4 and 6.8 in fried akaras; $\operatorname{In}^{26}$ report values for taste between 5.54 and 6.27. For the texture, average values are on the scale 'I do not like it, nor do I dislike', however 5 of the 60 tasters indicated that they were somewhat hard ${ }^{12}$ report values between 6.6 and 7.1. $\operatorname{In}^{26}$ evaluated sponginess as a textural attribute, obtaining values between 4.62 and 6.23. Regarding general acceptance, panelists preferred samples of the F1 formulation because of its array of attributes, placing them above the "I like it slightly" scale.

\section{Conclusions}

Color of bunuelos was influenced by variables temperature and formulation. The crust showed greater changes. On the contrary, the crumb maintained a more stable color. Analysis of the texture profile of the bunuelos was dependent on temperature and formulation. The bunuelos show good recovery from deformation, they are relatively hard, gummy, chewable, not very sticky and maintain their shape. Sensory analysis showed that, in general, the smell, taste, texture and color of cowpea bean bunuelos are slightly liked by consumers.

\section{References}

1. Plahar MA, Hung YC, McWatters KH, Phillips RD, Chinnan MS. Effect of saponins on the physical characteristics, composition and quality of akara (Fried cowpea paste) made from non-decorticated cream cowpeas. LWT - Food Science and Technology. 2006; 39(3):275-84. https://doi.org/10.1016/j.lwt.2005.01.003

2. Devarajan T. Chemical composition and nutritional potential of Vigna unguiculata ssp. cylindrica (Fabaceae). Journal of Food Biochemistry. 2005; 29(1):88-98. https://doi.org/10.1111/j.1745-4514.2005.00014.x

3. Maisale B, Patil B, Jalalpure S, Patil M, Attimarad L. Phytochemical properties and anthelmintic activity of
Vigna unguiculata Linn. Journal of Pharmaceutical and Scientific Innovation. 2012; 1(2):51-2.

4. Msika P, Saunois A, Leclere-Bienfait S, Baudoin C. Vigna unguiculata seed extract and compositions containing same. US Patents 2012/0237624A1. 2012.

5. Kita A, Lisinska G, Golubowska G. The effects of oils and frying temperatures on the texture and fat content of potato crisps. Food Chemistry. 2007; 102(1):1-5. https://doi.org/10.1016/j.foodchem.2005.08.038

6. Sanz T, Primo-Martin C, Van Vliet T. Characterization of crispness of French fries by fracture and acoustic measurements, effect of pre-frying and final frying times. Food Research International. 2007; 40(1):63-70. https://doi.org/10.1016/j.foodres.2006.07.013

7. Taiwo K, Baik O. Effects of pre-treatments on the shrinkage and textural properties of fried sweet potatoes. LWT - Food Science and Technology. 2007; 40(4):661-8. https://doi.org/10.1016/j.lwt.2006.03.005

8. Hleap JI, y Velasco VA. Analisis de las propiedades de textura durante el almacenamiento de salchichas elaboradas a partir de tilapia roja (Oreochromissp.). Biotecnologia en el Sector Agropecuario y Agroindustrial. 2010; 8(1):46-56.

9. Tavera-Quiroz MJ, Urriza M, Pinotti A, Bertola N. Plasticized methylcellulose coating for reducing oil uptake in potato chips. Journal of the Science of Food and Agriculture. 2012; 92(7):1346-53. https://doi.org/10.1002/jsfa.4704

10. Alvis A, y Velez C. Modelado del proceso de fritura del -ame (Dioscoreaalata) mediante mediciones reologicas usando la metodologia de superficie de respuesta. Informacion Tecnologica. 2008; 19(1):11-8.

11. Perusko M, Al-Hanish A, Cirkovic VT, Stanic-Vucinic D. Macromolecular crowding conditions enhance glycation and oxidation of whey proteins in ultrasound-induced Maillard reaction. Food Chemistry. 2015; 177:248-57. https://doi.org/10.1016/j.foodchem.2015.01.042 PMid:25660883

12. Patterson SP, McWatters KH, Hung YC, Chinnan MS. Phillips RD. Physico-chemical properties and consumer acceptability of akara (fried paste) made from three cowpea cultivars. Food Research International. 2002; 35(7):691-6. https://doi.org/10.1016/S0963-9969(01)00206-X

13. Melito HS, Farkas BE. Effect of infrared finishing process parameters on physical, mechanical, and sensory properties of par-fried, infrared-finished gluten-free donuts. Journal of Food Engineering. 2013, 117(3):399-407. https://doi.org/10.1016/j.jfoodeng.2013.03.012.

14. Ozkan M, Kirca A, Cemeroglu, B. Effect of moisture content on CIE color values in dried apricots. European Food Research and Technology. 2003; 216(3):217-9. https://doi.org/10.1007/s00217-002-0627-6. 
15. Prinyawiwatkul W, McWatters KH, Beuchat LR, Phillips RD. Functional characteristics of cowpea (Vigna unguiculata) flour and starch as affected by soaking, boiling, and fungal fermentation before milling. Food Chemistry. 1996; 58(4):361-72. https://doi.org/10.1016/S0308-8146(96)00259-2.

16. Rahman M, Al-Farsi S. Instrumental texture profile analysis (TPA) of date flesh as a function of moisture content. Journal of Food Engineering. 2005; 66(4):505-11. https:// doi.org/10.1016/j.jfoodeng.2004.04.022.

17. Teruel MR, Garcia-Segovia P, Martinez-Monzo J, Linares $\mathrm{MB}$, Garrido MD. Use of vacuum-frying in chicken nugget processing. Innovative Food Science \& Emerging Technologies. 2014; 26:482-9. https://doi.org/10.1016/j. ifset.2014.06.005.

18. Granados C, Acevedo D, Cabeza A, Lozano A. Analisis de perfil de textura en platanos pelipita, harton y topocho. Informacion Tecnologica. 2014; 25(5):35-40. https://doi. org/10.4067/S0718-07642014000500006.

19. Ziaiifar A, Heyd B, Courtois F. Investigation of effective thermal conductivity kinetics of crust and core regions of potato during deep-fat frying using a modified Lees method. Journal of Food Engineering. 2009; 95(3):373-8. https://doi.org/10.1016/j.jfoodeng.2009.05.015.

20. Caracteristicas texturales y de color en panes con mezclas de harinas. Publitec S.A. Disponible en: Available from: http:// www.publitec.com.ar/system/noticias.php?id_prod=414. Date accessed: 13/11/2018.

21. Hernandez M, Duran D. Caracteristicas reologicas del pan de agua producto autoctono de Pamplona (Norte de
Santander). Revista de la Facultad de Ciencias Basicas. 2010; 10(2):61-74.

22. De la Ossa Y, Rivera C. Analisis comparativo del perfil de textura de los quesos frescos de cabra y vaca, con relación al contenido de grasa y tiempo de almacenamiento. Universidad de Cartagena, Cartagena. 2012; p. 1-122.

23. Alvis A, Gonzalez A, Arrazola G. Efecto del recubrimiento comestible en las propiedades de trozos de batata (Ipomoeabatatas Lam) fritos por inmersion. Parte 2: Propiedades termofísicas y de transporte. Información Tecnologica. 2015; 26(1):103-16. https://doi.org/10.4067/ S0718-07642015000100012.

24. Morales M. Evaluacion de la adicion de emulsificantes y componentes fisiologicamente activos en la elaboración de bu-uelo. Universidad Nacional. Medellin. 2013; p. 43-4.

25. Bouchon P, Pyle DL. Modelling oil absorption during postfrying cooling: II: Solution of the mathematical model, model testing and simulations. Food and Bioproducts Processing. 2005; 83(4):261-72.https://doi.org/10.1205/ fbp.05114

26. Mbofung CM, Njintang YN, Waldron KW. Functional properties of cowpea-soy-dry red beans composite flour paste and sensorial characteristics of akara (deep fat fried food): effect of whipping conditions, $\mathrm{pH}$, temperature and salt concentration. Journal of Food Engineering. 2002; 54:207-14. https://doi.org/10.1016/S02608774(01)00196-0 